\title{
Research support from the Office of Naval Research
}

\author{
JOSEPH L. YOUNG \\ Office of Naval Research, Arlington, Virginia 22217
}

The operation of the Psychological Sciences Division of the Office of Naval Research is described briefly. Guidance is provided for prospective proposers of research to that division.

The Office of Naval Research (ONR) is the oldest governmental organization in the country funding basic scientific research in universities, nonprofit, and even profit-making enterprises. It was founded after World War II, and had the field essentially to itself until NSF was founded in 1950. But ONR has remained active in support of basic research to this day. As the name implies, the Office of Naval Research is a part of the Navy; the research we support, while basic in nature, is of the sort that might be expected to have eventual application in the Navy, say, in 5-25 years. More applied and developmental work is the mission of various in-house laboratories and centers.

ONR's Research Directorate is divided into a number of divisions, including the Psychological Sciences Division and the Biological and Medical Sciences Division. Table 1 lists names, address, and mail codes of all the relevant personnel. Donald P. Woodward, the Project Officer for Psychophysiology in the Physiology Programs of the Biological and Medical Sciences Division, is listed for completeness; his office is responsible for whatever physiological psychology work ONR funds. My remarks, however, deal with the Psychological Sciences Division, of which I am a member, and are most relevant to the Personnel and Training Research Programs, of which I am Assistant Director; specific practices may differ somewhat in Dr. Woodward's program.

The Psychological Sciences Division consists of three program offices. The Organizational Effectiveness Research Programs deal with the sorts of social psychological processes underlying the interactions in group situations which determine a group's effectiveness. The Engineering Psychology Programs deal chiefly with human performance, man-machine interactions, decision making, and problem solving. The Personnel and Training Research Programs have three main areas. The first is Personnel Measurement and Evaluation and

Reprint requests should be sent to Joseph L. Young, Personnel and Training Research Programs, Office of Naval Research (Code 458), Arlington, Virginia 22217. involves psychometrics, criterion development, and the like. A major emphasis in that area is computerized adaptive testing (David Weiss of the University of Minnesota is talking at this very moment in a competing session about the system he uses in some computerized adaptive testing research that we fund). The second area is Occupations and Careers, which involves industrial psychology issues. The third area is Training and Education, which involves learning, memory, cognitive psychology, computer-assisted instruction, and individual differences in cognitive processing. On-line computer systems are quite common in this last area.

We are ONR fund research, not facilities. Funds for facilities such as on-line computer systems may, of course, be included in research budgets, as required by the research proposed. Arrangements that have been used on occasion in our research contracts include lease and lease-purchase of dedicated systems, appropriate use charges for nondedicated systems, and a number of others.

The procedure for applying for ONR research support is the model of simplicity. One submits, through insti-

Table 1

Office of Naval Research

800 North Quincy Street, Arlington Virginia 22217

\begin{tabular}{c}
\hline Psychological Sciences Division \\
Glenn L. Bryan, Director \\
Organizational Effectiveness Research Programs (Code 452) \\
John A. Nagay, Director \\
Bert T. King, Associate Director \\
Engineering Psychology Programs (Code 455) \\
Martin A. Tolcott, Director \\
Gerald A. Malecki, Assistant Director \\
John J. O'Hare, Research Psychologist \\
Mersonnel and Training Research Programs (Code 458) \\
Joseph L. Young, Assistant Director \\
Biological and Medical Sciences Division (Code 440) \\
Physiology Programs (Code 441) \\
Donald P. Woodward, Project Officer for \\
Psychophysiology
\end{tabular}


tutional channels, a research proposal very much like a proposal to NSF or NIMH. The only difference is that the introduction might well be quite explicit as to the eventual Naval impact of the work. The scientific officers, listed in Table 1, then evaluate the proposal on the basis of scientific merit and centrality to the goals of their program, and decide whether or not to fund it. In practice, though, the procedure is a bit more interactive. Since the people who field preliminary inquiries are the same people who make final funding decisions, a preliminary inquiry is a good way to get a reading on whether it would be worthwhile to submit a full proposal.
A preliminary inquiry is often the start of a useful dialogue between the investigator and an ONR scientific officer. The dialogue continues as long as it is mutually beneficial. The decision to fund a particular bit of research is not the end of the dialogue, however. The funding instrument we use here at ONR is the contract, not the grant; it is not a conditional gift of money, but rather an agreement to provide money in exchange for research. The scientific officer and the investigator assume a collegial, mutually supportive, and cooperative role with respect to each other. It is this cooperative, collegial relationship with investigators that makes it so much fun for me to be at ONR. 